\title{
SEARCHING FOR THE HIDDEN GOD: THE INTIMACY OF SOUND AND LISTENING AMONG KRISHNA DEVOTEES IN MAYAPUR
}

\author{
MARJE ERMEL \\ Lecturer and PhD candidate \\ Cultural Theory / Social and Cultural Anthropology \\ Tallinn University, School of Humanities \\ Uus-Sadama 5, Tallinn 10120 \\ e-mail: marje.ermel@gmail.com
}

\begin{abstract}
This article looks at how the Krishna devotees in Mayapur, West Bengal, learn how to chant and listen to the sound of the holy name properly. They suggest that if one is 'pure' enough and knows how to listen one experiences the syneasthetic level of sound called pashyanti. At this level, one can reach beyond the duality of the 'hidden and manifested' worlds, the external and internal levels of sound; and one can ultimately see God face to face. This is also considered a level at which one can realise that the sound of God's name and God himself are the same. I will focus on how the devotees learn to create this sense of intimacy with God through the sound of his holy name, and argue that listening is not merely a process connected to our auditory sense but rather a creative and engaging activity, a skill that one can develop.
\end{abstract}

KEYWORDS: Hare Krishna devotees $\bullet$ religion $\bullet$ sound $\bullet$ skill $\bullet$ intimacy

INTRODUCTION

I am a beggar on the outskirts of the marketplace of the holy name. Can anyone spare me a crumb of faith, a drop of purification, steadiness, or taste, or even a little love for Krishna? (Kancana-Valli Devi Dasi)

In her book Crying for Krishna, Genevieve Brewster (2013: 32), with the initiated name Kancana-Valli Devi Dasi, captures the nature of the long journey of learning how to hear and chant the holy names of the Lord. She refers to the struggle to involve her whole being in the process of chanting and listening in order to develop an intimate relationship with God through the sound of his holy name. It is an intimacy that devotees frequently talk about but experience less often as presumably reaching this level needs years of devotion and skill.

In this article, I will explore the connection between sound and intimacy in the international Hare Krishna community in Mayapur, West Bengal. This relationship indicates that the collective and regulated practices may hide very personal and intimate experiences. I will discuss the role that sound and skilful listening play in creating a dynamic, 
embodied, and intimate space where the devotees can feel bhakti, loving devotion, and a very personal relationship with God. In particular, I will explore how the devotees study the right way to hear and chant through development of certain skills and qualities that relate to being a better devotee. A proper way of listening would help them reach beyond the duality of the 'hidden and manifested' realms, creating a sense of being simultaneously 'here and there.' Furthermore, this proper way of listening apparently helps them overcome the duality of external and internal levels of the sound of the holy name, which may ultimately lead to the realisation that the sound of God's name and God himself are the same.

Based on my experiences among Krishna devotees and the theoretical insights of researchers working with sound, I argue that listening is not merely a physical process connected to our auditory sense. It rather appears to be a perceptual and creative engagement with sound through which we simultaneously perceive and design the world we live in. Krishna devotees chant the holy names of God, which sound can change the way they perceive the world. The article addresses, to quote Brandon LaBelle (2010: xxvi), how "sound creates a relational geography that is most often emotional, contentious, fluid, and which stimulates a form of knowledge that moves in and out of the body" (original emphasis). Similarly, Michael Bull and Les Back (2004: 1) have referred to the power of sound to create emotional spaces that can enable both utopian and dystopian associations. They propose that sound allows individuals to create manageable, intimate and aesthetisised spaces to inhabit, but it can also become "an unwanted and deafening roar threatening the body politic of the subject". This approach seems to resemble the view of the devotees that sound can be both materially contaminating and spiritually purifying. The devotees believe that the sound of the holy name is a transcendental vibration that penetrates and purifies the bodies and the souls of both humans and non-humans and helps devotees to reach ultimate knowledge of God. For the devotees, ultimate knowledge is the intimate sense of Krishna's presence in his holy name and the realisation that Krishna is everything and everywhere. I suggest that this experience could also be understood as acoustemology, which, according to Steven Feld (2005: 185), is one's sonic way of knowing and being in the world, the way of being in which one makes sense of experiences through sound. For Krishna devotees, the constant process of learning to hear 'properly' is also a process of seeking a sonic knowledge and a sonic way of being in the world that demands a dynamic approach towards sound and listening and involves a deep sense of creativity and engagement.

\section{MAYAPUR, THE BIRTH PLACE OF KIRTAN}

The Krishna-bhakti movement of chanting the holy names of God was introduced by Krishna himself in the 16th century Mayapur, a little village on the banks of the Ganges river in the state of West Bengal, in eastern India. As a golden avatar, he appeared in the form of a saint and a devotee Chaitanya Mahaprabhu in order to experience and spread bhakti - the deepest loving devotion of God. According to devotees, the Srimad-Bhagavatam states that by the will of the Lord there was a lunar eclipse in the evening when the Lord appeared as Chaitanya Mahaprabhu. It was the custom of the Hindu public that during the eclipse one bathes in the Ganges or any other sacred river and chants 
the Vedic mantras for purification. Thus, during the birth of Lord Chaitanya, when the lunar eclipse occurred, "all India was roaring with the holy sound of Hare Krsna, Hare Krsna, Krsna Krsna, Hare Hare / Hare Rama, Hare Rama, Rama Rama, Hare Hare” (Advaita Candra Dasa et al. 2011: xv).

It is believed that this simultaneous appearance of Lord Chaitanya and the lunar eclipse indicated the particular mission of the Lord. This mission was to preach the loving devotion of God through chanting the 16 holy names of the Lord in this the age of Kali. It is suggested in the Upanisads and Puranas that among many other names of the Lord, these 16 names are particularly good for the age of Kali. According to the Bhagavad-Gita, the period of Kali will last for 432,000 years and is characterised as a time of ignorance, quarrelling, abundance of strife, vice and irreligion in which true virtue is nearly non-existent (Bhaktivedanta Swami Prabhupada 2009 [1972]: 461). Yet the sound of the holy names is believed to free a fallen soul from material conditioning. Therefore, Lord Chaitanya founded the Krishna-bhakti movement, the movement of loving devotion of God, and initiated sankirtan (also referred as kirtan), the practice of communal singing of God's holy names. The method of chanting the holy names of the Lord was meant for everybody, regardless their social background. According to devotees, it is stated in the scriptures that,

[T]he learned and the foolish, the rich and the poor, the Hindus and the Muslims, the Englishmen and the Indians, and the candalas [dog eaters] and the brahmanas [priestly class], can all hear the transcendental sounds and thus cleanse the dust of material association from the mirror of the heart (Advaita Candra Dasa et al. 2011: $\mathrm{xV}-\mathrm{Xvi}$.

In 1965, the movement was introduced in the West by an elderly man from Calcutta, A. C. Bhaktivedanta Swami, later known as Srila Prabhupada. At the age of 69, he travelled on the Jaladuta, a regular cargo carrier, from Calcutta to New York in order to fulfil the ancient Vedic prophesy that "[t]he holy name would be chanted in every town and village of the whole world". Since then, the international movement has become generally known as the Hare Krishna movement, or the International Society for Krishna Consciousness (ISKCON). As devotees would say, the 'holy name' spread quickly from New York to the different parts of the world, and in the early 1970s the first ISKCON devotees, in turn, started to settle in Mayapur, the birthplace of the movement. This ordinary Indian rural area, with few temples and huge expanses of green rice fields and other agricultural land, started to grow slowly into what the devotees would see as the headquarters of the ISKCON or the 'Kirtan Capital of the World', which began to welcome a growing number of international devotees who came on pilgrimage or settled down in the holy place.

Today, Mayapur is a rapidly growing city that probably draws its dwellers into a different sonic world than that of the 16th century. The smoothing flow of the Ganges and the different timbres of the variety of birds are still present. However, in addition to the sounds of nature and the growing variety of traffic sounds, Mayapur also has characteristics of a noisy construction site. Fulfilling the dream of Srila Prabhupada, the devotees are building the new Temple of the Vedic Planetarium, presumably the highest Hindu temple in the world, and houses that are growing like grass after rain to welcome the newcomers. At times, the sounds of drilling and polishing and the high pitch 
of knocking and sawing metal becomes a disturbing cacophony, creating the holistic sensational experience that your own body is under construction. As the sound artist Salome Voegelin (2010: 47) has written, "The body of the sound has moved so close it is my body: I am the host of noise" (original emphasis). However, I was told that it was up to the devotees and depended on their consciousness whether they would perceive those sounds as destructive construction sounds or a pleasing kirtan of a city that was growing for the Lord and his devotees.

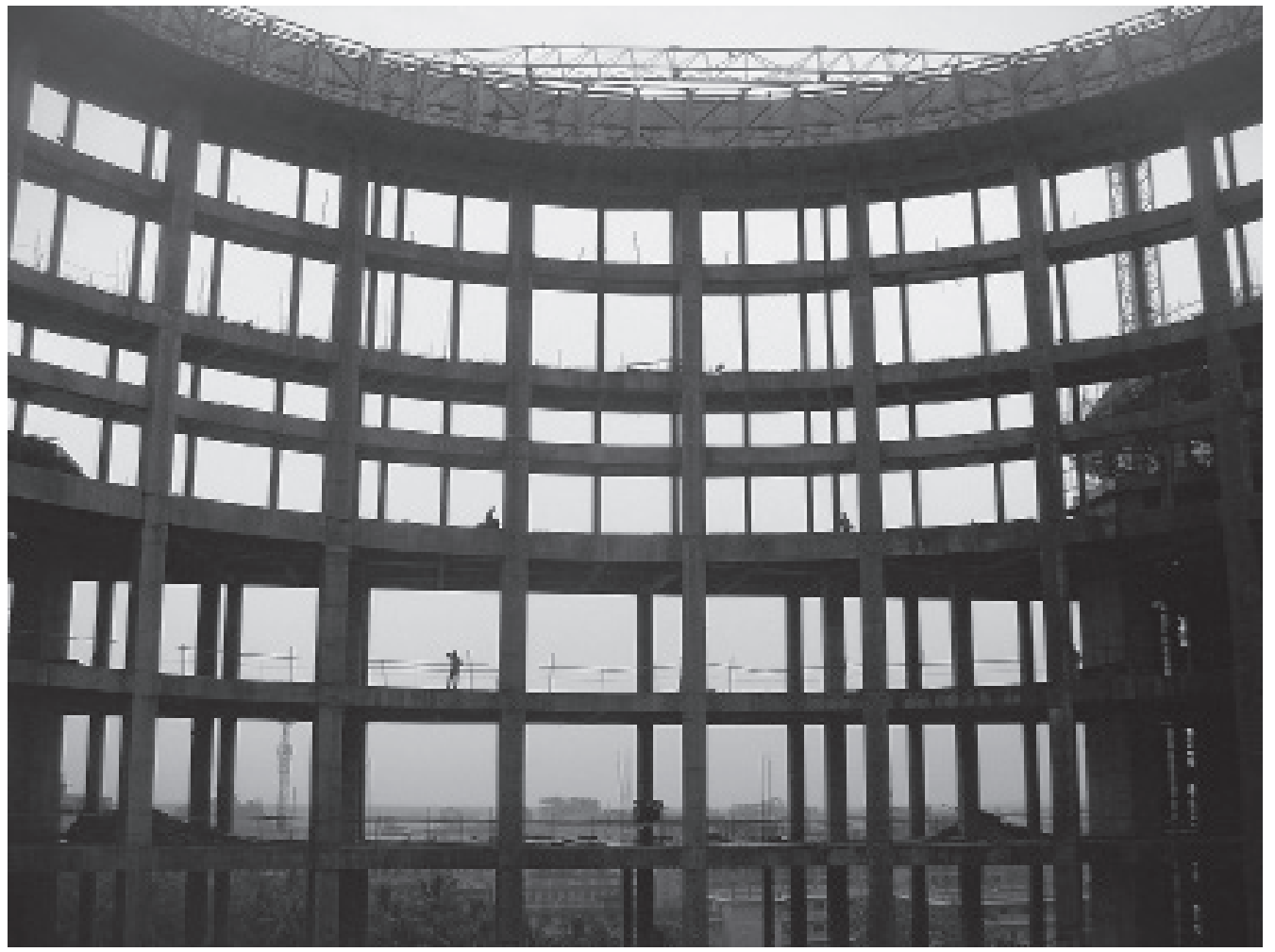

Photo 1. Temple of the Vedic Planetarium under construction. Photo by Marje Ermel.

Some devotees, however, find many of the sounds in the area rather mundane and distracting and therefore take shelter in the sound of the holy names. Following the teachings of Lord Chaitanya, the devotees who have settled in Mayapur or just come on pilgrimage keep spreading the sound of the holy names and thus revivify the sonic memory of the 16th-century sankirtan movement. They regularly dance, and sing the holy names of the Lord in the temple, on the streets, and on the roads of the nearby villages so that the transcendental sound vibration that believably emanates from the holy names would purify the hearts of all living entities in the area. The devotees chant the holy names on the boat trips and in the water of the Ganges in which the sound is believed to be thousand times more purifying. They go to the pilgrimages around the area of Mayapur where they chant the holy name along the way and listen to the stories of the pastimes of the Lord. In addition to the communal singing of the Lord's names at sankirtan, the devotees should also dedicate at least two hours per day for Japa mala 
meditation, which means at least 16 rounds of individual chanting of the Hare Krishna mantra using prayer beads. According to the scriptures, the God's activities, called lilas, are eternal and thus devotees claim that actually Lord Chaitanya still walks the fields in Mayapur and takes a bath in the Ganges. Devotees believe that those who have purified their consciousness through kirtan and japa can 'uncover' Mayapur and still perceive the presence and mercy of the Lord. This perception enables them to create a very intimate relationship with Krishna - with God who is simultaneously residing in his eternal spiritual sky as well as in Mayapur as Lord Chaitanya.

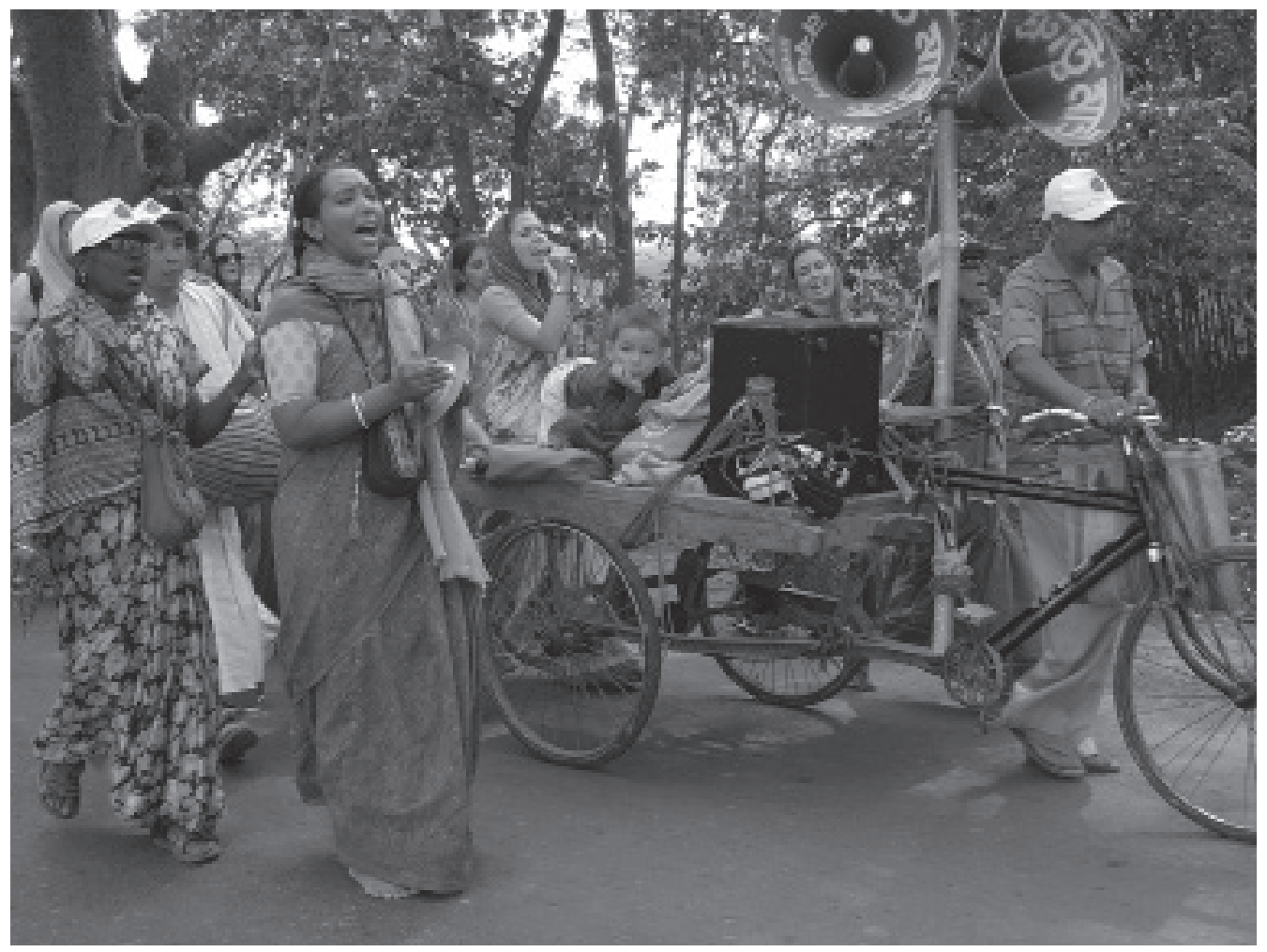

Photo 2. Devotees singing the holy names of God on Parikrama (pilgrimage) in Mayapur. Photo by Marje Ermel.

THE DYNAMIC LEARNING OF LISTENING

Even though it is believed that the devotees who have purified their souls can still perceive the presence of the Lord both in Mayapur and in his holy names, it is considered a very advanced stage of listening and perception. This refers to the possibility that through learning and practising one can actually change and develop the way one listens to the world. It also indicates that the way one perceives the world through one's senses is socially constructed rather than naturally given. In what follows, I will explore how this process, in which one can learn to perceive the world in a new way, takes place. 
Relying on Gibsonian ecological psychology, Tim Ingold (2000: 166-167) explains that there is an inexhaustible amount of information potentially available to an agent as there is no limit to what can be perceived. New things that people keep on seeing throughout their lives in an otherwise permanent world are perceived not by constructing the same sense data according to a novel conceptual schemata but by sensitisation or the fine-tuning of the perceptual system to new kinds of information. Therefore new perceptions do not arise so much from imagining as from creative acts of discovery, in addition to which the information on which these perceptions are based is available to anyone attuned to picking it up. Ingold concludes by suggesting that the way one perceives the world through one's senses is learnt and thus socially constructed. He explains that,

One learns to perceive in the manner appropriate to a culture, not by acquiring programmes or conceptual schemata for organizing sensory data into higher-order representations, but by 'hands-on' training in everyday tasks whose successful fulfilment requires a practised ability to notice and to respond fluently to salient aspects to the environment (ibid.: 167).

James J. Gibson (1979: 254) has noted that the process of learning can be seen as an "education of attention". Therefore, Ingold (2000: 167) concludes, learning should not be viewed as a transmission of information but rather as tuning one's perception, which continues for the whole of one's life.

Paul Stoller (1984: 560) has given a provocative example of the experience of learning to tune one's senses in a culturally specific way. As an anthropologist and apprentice of a Songhay sorcerer in Niger, he recalls his own failure to perceive a sick man's spiritual double, which had been separated from the man through witchcraft. Stoller had failed to 'hear' the double's return after the healer had discovered it in a pile of millet husks. He recalls his conversation with his teacher Sorko Seyni Mounmouni, who had given him his "first lesson in Songhay hearing":

He turned toward me: "Did you hear it?"

"Hear what?" I asked dumbfounded.

"Did you feel it?"

"Feel what?" I wondered.

"Did you see it?"

"What are you talking about?" I demanded.

Sorko Seyni shook his head in disbelief. [...] He said to me: "You look, but you do not see. You touch, but you do not feel. You listen, but you do not hear. Without sight or touch," he continued, "one can learn a great deal. But you must learn how to hear, or you will learn little about our ways."

Theatre director and performer Phillip B. Zarrilli (2015: 121) also suggests that longterm, in-depth practice can potentially open specific sensory/experiential "worlds". In particular, he focuses on meditation, martial arts, and acting/performance, and suggests that one can progressively unfold or elaborate a distinct complexity or "thickness of sensing" that creates the living "world" of that practice. He proposes that by paying attention to, and opening one's awareness of, one can reach the experience of "what it is like" to inhabit/sense/live within that specific "world". Zarrilli (2015: 122) poses the 
question, "How does one learn 'to be sentient' and 'to open up a world,' yielding to the resonance 'within' offered by that specific 'world'?"

I would suggest that the process of chanting the holy names can also shape one's sense of hearing in a culturally specific way. Furthermore, this process can also be viewed as a form of meditation that enables the practitioner to inhabit/sense/live within a particular world where certain kinds of sensibility become possible. Reaching this experience, I propose, demands a very steady and dynamic practice focusing primarily on the skill of listening. As when Stoller was asked to learn to be sentient and tune his hearing in a certain way, Krishna devotees told me that "there is no researching without chanting and hearing the Hare Krishna mantra". Relying on his fieldwork experience, Stoller describes how important it had been to let the sights, sounds, smells, and tastes of Niger to flow into him. He highlights what he believes to be the fundamental rule in epistemological humility - one cannot separate thought from feeling and action as they are inextricably linked (Stoller 1989: 5). Thomas J. Csordas (1994: 269) also claims that embodiment is a methodological standpoint in which bodily experience is understood as the existential ground between culture and self, and therefore considered as a valuable starting point for their analysis. In a similar manner, I realised that in order to understand the experience of chanting and listening, I had to be fully engaged in practice and take my experiences seriously.

To explore how this listening is taught, I joined a course called The Kirtan Academy, which lasted three months over the winter. During the course, devotees had a chance to learn the main musical instruments used in the kirtan such as the mridanga, harmonium, and cartals. However, the main focus was on learning the proper way of chanting and hearing the holy names. Doyal Gouranga Das, the co-founder of the Kirtan Academy, who moved to Mayapur from Germany in 2010, explained that even though it was called a Kirtan Academy, it was actually the Holy Name School. He said that it was not primarily about music or the ability to sing nicely. It was rather about understanding the holy names from different angles and becoming aware of the various qualities one should cultivate in oneself in order to be a good chanter.

Sravanam and kirtanam are considered the first and the most important processes of developing bhakti, loving devotion of God. According to Doyal Gouranga, sravanam means 'to hear', to receive the transcendental information through one's ears. Kirtanam means 'to speak, sing, describe' the glories of the Lord. Gouranga pointed out that there are four different types of kirtan. In nama kirtan, one speaks about the name of the object of one's kirtan. In rupa kirtan, one speaks about the form of the object of one's kirtan. In guna kirtan, one speaks about the qualities of the object of one's kirtan; and in lila kirtan, one speaks about the activities or the pastimes of the object of one's kirtan. He explained further that the highest object of kirtan was God. Thus devotees sing the name of God and accordingly describe his form, his qualities, or his activities, as pastimes. "Out of four types of kirtan," he continued, "the kirtan of the name is the most important". He referred to the age of Kali, in which, as mentioned above, the only way to liberate the conditioned soul is to chant the holy names of the Lord.

The goal of the academy, to teach people how to chant and hear the holy names properly, seems to support the view that our senses are socially constructed and that one can fine-tune the way one perceives the world. More particularly, this view shows that listening is a skill one can learn and that the practice of listening involves much 
more than just the auditory sense. I remember that one of those chanting days in the Kirtan Academy showed the very dynamic nature of listening. It was the beginning of February, an early spring day in India when the fresh mornings are still shrouded in cold and humid night fog, although the days are warm and sunny. It was the day of preparation for the ' 64 rounds day'. This was a special day in the Kirtan Academy that happens once a week when, instead of the regular 16 rounds, the devotees were encouraged to chant the mantra 64 rounds using their prayer beads. This would take approximately eight hours for an experienced chanter. The preparation day was necessary because, according to the teacher Bhakti Brhat Bhagavat Swami, it takes about 12 hours to prepare one's consciousness for an event like this.

Bhakti Brhat Bhagavat Swami reminded the devotees of the meaning of the Hare Krishna mantra, explaining that it simply means addressing God and his energy, Hara. The mantra expresses the prayer "Oh energy of Krishna, oh Krishna, please engage me in your devotional service!" In his book The Nectarian Ocean of The Holy Name, guru Sacinandana Swami (2010 [2006]: 36) explains further that Krsna means 'the all-attractive'; that the syllable $k r s$ can be seen as the attractive aspect of the Lord and na originates from the word ananda, 'spiritual bliss'. Thus, he suggests that "the name of Krshna contains God's most attractive and pleasant aspect". He explains that Rama refers to spiritual enjoyment and Hare is the addressing form or vocative case of Hari and is also another name for Krsna, "He who grants liberation". Yet Bhakti Brhat Bhagavat Swami suggested that devotees were often not focused or aware of the meaning and importance of chanting. He explained that such inattentive chanting was viewed as mechanical chanting and was considered one of the biggest offences towards the holy name. He explained that mechanical japa meant that devotees were doing something else along with their chanting and thus not focusing on the sound of the mantra. He had the whole list of different types of inattentive chanting which the students in groups had to act out in front of others. They were asked to make various performances of a driving japa, a newspaper japa, a sightseeing japa, a mobile phone japa, a cooking japa, a cleaning japa, a shopping japa, a 'to do list' japa, an Internet japa, a TV or movie japa, a Bhagavatam class japa, a kirtan japa, and the list went on. The devotees found the performances simultaneously funny and serious as many of them recognised their own mistakes in these role-plays. The performances made the ways in which one is not supposed to chant the individual japa visible. And even though the devotees are generally aware of the importance of attentiveness, the common scene in Mayapur is a devotee with his or her hand in a japa bag, murmuring the holy name, while simultaneously talking to a friend, doing laundry, checking Facebook, listening to kirtan, or shopping. This inattentiveness is considered offensive towards the holy name and one of the aims of the Kirtan Academy was to deepen the devotee's awareness of such challenges in the process of developing one's Krishna consciousness.

Hence, Bhakti Brhat Bhagavat Swami reminded devotees of the basics of the chanting - to focus on the sound and to hear all the 16 words and the 32 syllables of the mantra. It was important to pronounce all 32 syllables properly and loudly, simultaneously hearing them attentively. He also explained that the best chanting time was early in the morning; that we should find our own comfortable place for chanting; that we should sit properly while chanting; that we should involve both our upper and lower lips as well as the tongue while chanting; and, once again, the words "Hare Krishna" 
should be very distinctly pronounced and heard. He warned devotees not to be tricked by their minds during the ' 64 rounds day'. He explained how our mind would distract our chanting by telling us to go and drink some water, to go to the wash-room, to have a rest, to ask how many rounds our friends had chanted, and many other disturbing things. He insisted: "You are not the mind! Take a vow of silence, Mauna Vrata, on the mind, do not listen to the mind! Please continue to chant, even if you are not attentive, just chant, never give up chanting." He emphasised that we should hear the sound, not the mind, as the thinking factor of the mind and the hearing factor of the mind would not function simultaneously. "You either think or you hear," he claimed in a nutshell.

Describing the acting and meditation training processes, Phillip Zarrilli (2015: 127128) similarly notes that the practitioner begins to develop what is often referred to as "concentrative", "focused attention", or "contentless awareness of the mind". This is the ability "to direct and sustain attention on a specific object". Various attentive practices, as Zarrilli points out, are particularly meant for "learning to still the mind, direct one's attention, and thereby quiet a too often naturally busy brain, "monkey-mind", or "squirrel-like" mind that races here and there. (Ibid.: 128) For Krishna devotees, this "specific object" to focus on, as Bhakti Brhat Bhagavat Swami also reiterated, is the sound of the holy name. As Doyal Gouranga emphasised, the sound of the holy name is the "object of kirtan". He also pointed out that the goal of any mantra was to "liberate yourself from your mind". Similarly to Bhakti Brhat Bhagavat Swami, he explained that our mind took us either in the future or in the past. It is constantly unsated and never gets tired. Yet, if we are in the present, the mind is still. However, he admitted that this stage of stillness is not easy to reach:

If we are attentive we concentrate on the vibration, the sound of the mantra. [...] You pray for the attention because attention... it's not a cheap thing. We pray, "Please, let me hear your name!" Then, very quickly nectar starts coming, very quickly. Without attention you can forget about the nectar, really [....] If we do it properly, just with the full respect and attention: chanting the name, hearing it; again chanting; again hearing... Don't worry about the speed, don't worry about time, about circumstances! When you do it, just do it! Concentrate on this! Then, this is real kirtan. And it very quickly changes us to a much much better person and ultimately to a spiritual being.

I joined the '64 rounds day' in the Kirtan Academy in the late morning. The academy was actually just a nicely decorated shelter in the park not too far from the temple and next to the boys' international school and Goshala, an ISKCON cow farm. This was a temporary place. However, even the permanent 'holy name village' that they were planning to build both for teaching and for the accommodation of students, would not differ significantly. As Yasomati Devi Dasi, the founder of the Kirtan Academy, told me, the place for the academy would still be eco-friendly and very simple, consisting of lots of trees and gardens and mud huts with straw roofs. When I arrived, around 15 devotees were sitting under this temporary shelter, still wrapped in the blankets that had protected them from the cold morning fog. Now the day was already hot, and the strong yet sleepy and monotonous sound of murmuring mantra felt like an irresistible lullaby sung by a cloud of honey-bees. Those who arrived early had chanted nearly half of their 64 rounds. Many devotees were struggling to stay awake, probably from 
the combination of the heat and lack of sleep. Even a white dog close to the shelter, which had carelessly watched the devotees chanting, finally gave up and fell asleep. Following the devotees, I sat down in the lotus position on a light coloured carpet covering the earth under the shelter. I took out my prayer beads and started repeating the holy names. Touching the biggest wooden bead in the row of the 108 beads between my thumb and my middle finger, I chanted, "Sri-krishna-chaitanya prabhu nityananda sri-adwaita gadadhara shrivasadi-gaura-bhakta-vrinda". As the devotees told me, it was good to chant this mantra before every round to get the Lord Chaitanya's mercy and forgiveness for whatever offenses one may commit while chanting the Hare Krishna mantra. Then I calmly continued the round, feeling the strong wooden prayer beads gently moving one after another between my fingers. The sound of my monotonous and rather quiet chanting "Hare Krishna Hare Krishna Krishna Krishna Hare Hare, Hare Rama Hare Rama Rama Rama Hare Hare" merged with the sound of the devotees chanting next to me and the cacophony of the birds and construction sounds in the area. Few sounds from the outside world were enough to break my concentration and to activate my mind to observe my surroundings and ask several questions:

How many rounds have they chanted already? Did they really wake up at two o'clock in the morning, as suggested? What do they experience while chanting? Am I ever going to understand this? Do they feel 'Krishna's presence'? Can they really focus only on sound? Is their mind wondering around like mine?

Some devotees experienced similar difficulties, as I learned later. Premalata Devi Dasi, a devotee from the Czech Republic, shared her experience of the ' 64 rounds day'. She expressed her surprise that the warnings by the teachers about the wondering mind became a detailed reality once she started the long process of chanting. She recalled:

And it came, everything, you know... In one moment, you start to feel very tired and you really need to sleep. And then... if you say, "No, you know, let me chant few more rounds and then we go and take some rest for a short time"... okey, [now] the mind is satisfied and you can chant. Finally you realise, "I'm not tired at all!" [...] And then you become so hungry. You have to eat something, otherwise you die. You feel even dizzy. You feel such a pain in your stomach. And then, "Okey, let me chant four more rounds and then we will go and take something." [The hunger is] immediately gone! You cheat your mind and then you realise that he [the mind] was trying to cheat [you]! [...] And then another stage is when you try to kind of investigate how many rounds your neighbour has done. And if he has done less then your mind is kind of like patting your false ego, "I'm so good, I'm so good!" And then you don't think of Krishna, but how you are good... And if by chance your neighbour has done more, then your mind is beating you, "You are so useless, useless, useless!" Not thinking of Krishna, just thinking how you are bad... "Better give up you know. Give up, let's go... go take some ice-cream!"

Premalata admitted that before she had developed the desire to chant 64 rounds, chanting so many rounds had been like pushing the heavy stone in front of her. But once she developed the desire the process became easier. She said:

I was kind of thinking that actually this is such a sweet... this holy name. It's real nectar. And even if I will not make it, let me drink as much nectar as I can. And 
it made me like peaceful and I could continue. It was very sweet and then... [I chanted] 32 [rounds] without a problem. [...] And then you go further, you know. If you go up to 48 [rounds], it's like... you become tired, because we are not used to it. But you know, I'm gonna make it! And then, as Bhakti Brhat Bhagavat Swami said, "Once you do the 64, you realise that you want to chant even more. And if you are really prepared for that, prepared your mind for that and meditate upon it, then you are able to do much more." [...] And actually, from that moment [...] when I developed the desire that I want to chant 64 [rounds], it was like... it changed the point of view. Now it's not so heavy [...] and still I'm not there [yet], but it's not so difficult.

Premalata's story refers to the steady and dynamic process of learning to develop the desire and the skill to be able to chant and experience a certain state, which she describes as tasting a sweet nectar. However, this taste seems to have different qualities that one learns to discriminate in order to evaluate one's own development in Krishna consciousness. I suggest that Zarrilli, emphasising the subtle changes in the actors' experiences, also provides an insight into the process by which the devotee's experience of listening to the holy names changes over time. Zarrillli seem to propose that as one continues the exercises daily, one cannot notice great changes in the intensity and amplitude. He argues, "What does alter over time is the degree, type, and quality of the 'felt' sense of connection; what inhabiting the exercises is 'like'"' (Zarrilli 2015: 128, original emphasis). At the beginning of the practice, there is only little "that it is like". One needs sufficient repetition and experience to attune oneself to what is feasible within the exercises. Zarrilli proposes that "what it is like" only appears over time and changes in a similar manner how the perfumer learns to have a discriminating sense of smell, or how the expert wine taster develops the subtle skill to discriminate and "taste" the quality of the "feeling". (Ibid.: 130)

Doyal Gouranga emphasised that the goal of kirtan was prema, the love of God, and chanting was the best and the easiest way to awaken that love in one's heart. Similary to Zarrilli, he emphasised the necessity of long-term practice in order to gradually attune oneself to fully experience what the practise had to offer. He explained:

So, by practising the holy name you start loving the holy name. You start realising God in the holy name. And when you develop love for him you don't want to stop chanting because that's how you associate with him, always. So, the perfection of chanting is more chanting. And it's a very tasty process. In the beginning it can be bitter. [...] Our great great saint and teacher Rupa Goswami writes [...] that the holy name is sweet like a sugar candy, but we feel it bitter. And the example is that when you take a sugar candy and you have jaundice, then it tastes bitter. But the ayurvedic science says that you can cure the jaundice by taking the sugar candy regularly. So, you take the sweet candy, which is by nature sweet but it tastes bitter to you. But you take the sweet candy again and again and it cuts the disease at the root. The same with the names. If you take the holy names, again and again, as much as you can, slowly slowly it will cut our diseased material condition. It's really nectar, but we have to come to this stage. In this material condition, I have the problem, and this [the Hare Krishna mantra] is the medicine. And I have to take it deliberately. And to make it more sweet for us, we need to be very attentive. 


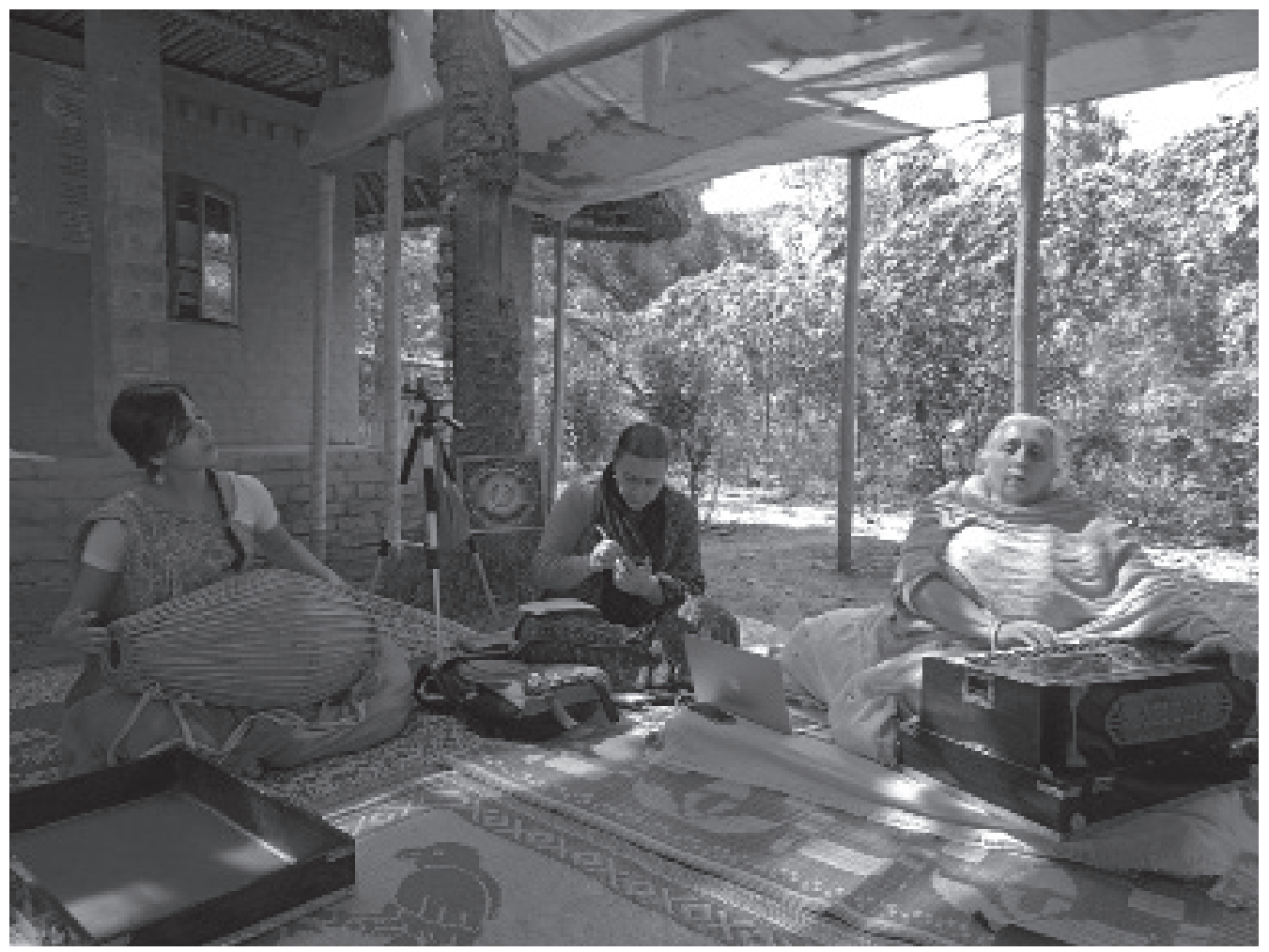

Photo 3. Yasomati Devi Dasi (on the right) with her students in the Kirtan Academy. Photo by Marje Ermel.

While participating in the ' 64 rounds day' in the Kirtan Academy, I finally managed to take the teachings of both Doyal Gouranga and Bhakti Brhat Bhagavat Swami more seriously and tried to quiet my mind, focusing only on the sound of the mantra. Bhakti Brhat Bhagavat Swami had said, "Just chant louder so that you wouldn't hear your mind!" However, in this process not only was the sound of the mantra present, but other sounds also became very present. With my eyes closed, I could hear various sounds from different directions hitting and penetrating my body: the rhythmical high pitch of knocking, melodious beeping, a tintinnabulating beeping from the right; a strong scrabble and rustling movement from one side to another behind me; the sound of someone flopping down and the low beat of bouncing further to the front; and a monotonous murmur on the left.

This experience reminded me of the practice of reduced listening. Michel Chion (2012: 50) explains this as a mode of listening that focuses on the characteristics of the sound itself, independent of meaning and cause. Regardless of whether it is verbal, played on an instrument, noises, or in any other form, Chion seems to claim that reduced listening takes the sound itself as an object to be observed rather than as a vehicle for something else. He would also argue that reduced listening helps us open our ears and sharpen our power of listening. He suggests that this development of a listening skill through reduced listening happens because "[t]he emotional, physical, and aesthetic value of a 
sound is linked not only to the causal explanation we attribute to it but also to its own qualities of timbre and texture, to its own personal vibration" (ibid.: 51). While exploring the role of different senses in complementary and alternative medicine, Ruth Barcan (2011: 140) similarly suggests that sound is a tool. But it is not just a pathway to meaning that just represents or signifies. It does physical things. What it is, what it does, and also what it means cannot be completely separated.

However, the devotees were not supposed to focus on the qualities of many different sounds. They were asked to focus only on one sound - the sound of the holy name that they themselves were producing in the very moment. It did not seem an easy task in this sonic ocean in which waves with different vibration patterns were bombarding us from various directions. I continued trying with my eyes open. Now my mind started easily reflecting on what I saw. It was early spring, yet the big yellow Sal tree leaves falling in the warm wind and sunlight gave me the feeling of an Estonian 'old women's summer'. It is also called an 'Indian summer' in the Northern Hemisphere, referring to unseasonably dry and warm weather in Autumn. I also remembered the previous August when the same park was decorated with flowers and little lights for a festival where the devotees could swing the deities, sing kirtan for them, and tell stories about the pastimes of the Lord. This had been in the late summer in unbearable heat and humidity. Yet finally, I remembered to bring my mind back from these far away journeys of the places and memories. I was reminded that "it is hard to think and listen to the qualities of the sound at the same time". I started chanting louder and finally managed to focus for a while only on the sound of the mantra. After some time, my mind became quieter and I realised that the scenes around me did not trigger my memories and thoughts anymore but were rather filled with life and a sense of presence, with no past and no future. It felt as if the same light, dry Sal tree leaf that was silently floating in the warm wind towards the dry ground was carrying in itself the whole of life and all the creative potency of the present moment. The colours around became more vivid; the contours of the trees and bushes became sharper.

I view this experience as a temporary change in perception evoked by sound and a specific way of listening. Voegelin (2010: 5) proposes that the practice of listening remains incomplete in relation to an objective totality, but it remains complete in its subjective contingency. She suggests that sound, if listened to generatively, is to produce, to be in motion. It is "an invisible act, a dynamic of production that is not interested to linger and hear its outcome. It is perpetually on the move, making time and tenses rather than following them." (Ibid.: 14) This proposes that the world we listen to is always in the process of becoming. We can share the goals and the specific practices of listening but the experience is always subjective depending on one's particular skills. I would propose that for devotees, in a similar vein, the experienced intimacy with Krishna in his holy name is always subjective, depending on the skills one has developed.

Bhakti Brhat Bhagavat Swami explained further that these skills did not involve only the ability of attentiveness. He clarified that the goal was to reach "the heart in chanting", and at this stage one wanted to be private and personal; one wanted to be with Krishna. However, to be able to experience Krishna's presence in his name demands much more dynamic learning than just focusing on the sound. As the goal is to experience Krishna's presence as a person, one has to engage with him on a personal level. 
This means that, for Krishna devotees, learning to listen requires them to develop their personality on a much deeper and more existential plane.

Devotees say that the main quality one has to develop in order to acquire the skills of listening is humility. As Srila Prabhupada explains in the commentaries to the Bhagavad Gita, the beginning of knowledge is amanitva, humility. Without humility one is not capable of understanding. Therefore a devotee should be humble and know his or her subordination to God Krishna. Thus, it is believed that the process of learning begins by practising humility, and it gradually culminates in reaching the ultimate knowledge of Krishna (Bhaktivedanta VedaBase webpage). Doyal Gouranga explained that bhakti was all about pleasing the Lord and getting His mercy. He said:

If we are doing it in a most respectful, concentrated and attentive way, it shows to God how much we want his mercy. Then he opens something; then we go to another level. He is pleased; he is uplifting us. As soon as we become proud we lose our concentration, we lose our qualification.

Therefore, he added, one of the most important verses they taught in the Kirtan Academy was the verse from Lord Chaitanya himself, describing the proper state of mind for a chanter: "Be more humble than a blade of grass, more tolerant than a tree, always offering respect to others and never expecting any in return".

Vikram Aditiyan, a young student from South India, explained that if one chanted with the right attitude and the right mood one would have the feeling of ecstasy and fulfilment. "You feel full, there is like nothing lacking within you anymore," he said and added that during every ' 64 rounds day' he had felt as if a caterpillar was becoming a butterfly. He felt that he was attaining a new level and was "literally coming out from the old and getting into the new". Referring to qualities that his teacher Bhakti Brhat Bhagavat Swami had emphasised, Vikram also suggested that chanting was not a mechanical process. He referred to the words of one of their great acharyas (spiritual leaders) Bhaktivinod Dhakur, who had said that mechanically one could chant for millions of years, millions of lifetimes, but one would get nowhere because chanting was the process of connecting the heart to the Lord. Vikram explained:

Your heart has been blocked and covered by the dust of material consciousness. It has been covered by millions of lifetimes of conditioning [...] So no matter how much mantra you hear, it's not entering your heart. For the mantra to enter the heart the dust has to be removed, the heart has to be open.

Certain qualities, Vikram suggested, were necessary in order to open the heart. In addition to the importance of humility, Vikram also emphasised the significance of gratitude. He referred to Radhanath Swami, one of the highly respected ISKCON gurus, who has said: "Gratitude is the field where the seed of bhakti can grow." Vikram explained that if one felt grateful even for the little things around, it would affect the quality of the chanting. He said, "Then... every round you do, you feel the round and you connect yourself to the holy name. You hear the name and you allow it to sink into your consciousness, into your heart." The other quality, humility, is believed to be the true nature of the soul and, according to Vikram, the soul has to be close to its true original nature for the sound of the God's name to flow into one's heart. He explained that humility would align devotee's consciousness and remove the blockages. He said that one had to align 
oneself in such a way that "mercy flows, everything flows, and one is in full God consciousness".

The teachers in the Kirtan Academy as well as other senior devotees were often admired in the community because of these 'pure qualities'. The devotees found such people as a source of inspiration and motivation to develop their own attention and desire to hear the holy names. Kay Milton (2002) suggests that actually attention itself can be viewed in terms of emotion. We may learn what to love and fear, enjoy or hate by perceiving these emotions in others. Even though the feelings of others are not directly perceivable, one can infer them by observing the way they look and behave. (Milton 2002: 68-69) I propose that perceiving the sense of gratitude and humility in other devotees seems to inspire the young chanters to dedicate themselves for more chanting and hearing the holy names. This encourages them to practice more and thus to become more skilful by attuning the sense of hearing in order to fully experience "what it is like" to inhabit the specific world of the sound of God's names.

\section{EXPERIENCING THE HIDDEN GOD}

What is this experience, however, that the devotees are aiming to achieve through these dedicated hours of practice? What is it like to "inhabit/sense/live within that specific 'world"' (Zarrilli 2015: 121) in which a devotee experiences an intimate relationship with the Lord? Similarly to Zarrilli, I assume that there are states of consciousness (or modes of conscious awareness) that we call ordinary and between and among these ordinary states there are transition or borderline experiences (Zarrilli 2015: 123). These different states of consciousness organise our experiences, physiology, cognition, and behaviour. While being aware of the variety of individual experiences in these practices, Zarrilli (ibid.) proposes that from a phenomenological perspective, meditation, martial arts, and acting, can all be viewed as "modes of embodied practice whose purpose is to shape socio-culturally, aesthetically, and/or historically specific forms of extra-ordinary, non-dual phenomenal consciousness that are somehow different from one's ordinary states of consciousness and experience" (original emphasis). He emphasises that when one develops and sustains a specific discrete altered (or alternative) state of consciousness, new ways of logics and perception emerge. Furhermore, he argues (ibid.: 123), "new modes of deploying one's sensory awareness and/or active imagination are also shaped and experienced".

For the Krishna devotees, the new or extra-ordinary ways of perception, as indicated above, may vary in depth and perhaps in the scope of intimacy. This was vividly explained and illustrated in a conversation with Gita Nagari Das. He joined the movement in the United States in 1979 and has spent the last 12 years in different holy places in India - mainly Vrindavan, Jagganath Puri, and the last few years in Mayapur. As he said, his service to Krishna and for the community was to lead a little group of devotees singing and dancing kirtan on the main road and sometimes through the little nearby Bengali villages. When I asked him about the holy name, he explained to me that in contrast to the spiritual world, God was hiding himself in this material world; he had to hide because people in this world did not want him. However, as his spiritual master had said, God was leaving clues all over the place that he exists. But in order to discover 
God or bring him out of hiding, devotees chant the Hare Krishna mantra. The sound vibration of chanting would bring God out of hiding. He explained further that this would happen because God was a reciprocatory being. "When Krishna sees that someone is attempting to approach him, then he will reveal himself to that person to show that he is there," Gita Nagari said and admitted that this revelation was so profound, so earth shattering and so life changing that one was achieving a state of mind that was all one wanted.

His response to my question about his own chanting experience highlighted the unusual state of awareness or consciousness one can reach through sound. He explained:

You know, the thing is that [...] according to Vaishnava philosophy, it is considered [...] one should not talk about one's ecstasies. Do you understand? So, your question is pointing at ecstasy. [...] Well, the thing is that... one doesn't stay for 33, 34, 35 years in Hare Krishna movement unless he has some experience. Experience of God is a very private thing. But to help you out, there have been times in my Krishna consciousness, not very often, when I was chanting the Hare Krishna mantra and it was so powerfully affecting me that I couldn't even chant it... the voice becomes choked up... tears come to the eyes, the body experiences incredible emotion, and... one becomes transported to the whole other Dham [holy place].

He added that there were some devotees who were capable of maintaining this state of God consciousness all the time. However, he claimed that for him this experience was rare, and even though he had been a devotee for 37 years, he still could not say that he had joined Krishna consciousness. He saw it as a lifelong endeavour, even the endeavour of many lifetimes, and claimed that, "You can actually say that you have 'joined' Krishna consciousness if you have seen God face to face. Then you have really joined Krishna consciousness."

A somewhat similar story was told by Yasomati, the founder of the Kritan Academy, who was one of the first devotees in the ISCKON and who had moved to Mayapur from Canada. She said, "Chanting is a wonderful place to be. When you are chanting... this is the way you can really come to Krishna and call out his name. He is present in his name." "Do you feel like you are in another place?" I asked. "Not every day. Not every day. It just sometimes feels like there is nothing else that you would rather be doing. This is it, just... just chanting," she replied.

That the sound of chanting brings God out from hiding, enabling a devotee to experience being transported to another sacred place, and ultimately allowing a devotee to see God face to face, illustrates the power of sound to create an intimate experience of the hidden or unmanifested world. As indicated in the story of Gita Nagari Das, this 'revelation' through sound seems to be first and foremost a bodily experience. Peregrine Horden (2000: 6), emphasising how sound can effect the body, explains that the body's rhythmicity is not closed. The body is open to be influenced by external sounds. Cells are dynamic and vibrating structures that can be influenced and altered by sound vibrations. Barcan also explains that music can stir emotions and bypass rationality. Its ambiguity extends to the domain of religion, where it can act as a stirrer of the flesh as well as "the agent of the sacred" (Dolar 2006: 31; cit. Barcan 2011: 131). The experiences of Gita Nagari Das and Yasomati also remind me of the reflections by a contemporary composer of religious music John Tavener, who describes his sonic expe- 
rience of his own work by referring to the notion of temenos, of sacred place. Musicologist Sander van Maas (2008: 768-769) explains that this is not an indication only to his concert spaces, but more particularly to the specific spatiality music can itself produce qua place or temenos. For experiencing music as a place, or as a multiplicity of places, van Maas argues that one has to be engaged, in a wholly dependent way, in the situation called music on the level of participation. Music becomes a heterotopia that, at the aural-sensible level, actualises the seemingly impossible mode of being - being simultaneously here and there, inside and outside - a mode of being of which only the gods are believed to be capable.

Stoller (1984: 559) who has studied the 'inner' dimension of sound in Songhay cultural experience also emphasises the intimate corporeal experience of sound. Similarly to the view of Krishna devotees, who believe that the sound vibration of the mantra penetrates and purifies one's heart transforming a person into a higher level of consciousness, Stoller suggests that Songhay people also believe that sound can carry forces that can penetrate an object. They similarly claim that certain sounds such as magical words, praise names, and sacred musical instruments create "an auditory presence that can transform a person morally, politically, and magically" (ibid.: 563). Stoller also proposes that by penetrating the individual, sound creates a sense of participation and communication. He suggests that sound is a foundation of the flowing and dynamic world in which the outer and inner worlds interpenetrate. (Ibid.) Voegelin (2010: 12) has similarly written that sound has the ability to unsettle the idea of visual stability and involve listeners in the production of an invisible world. She also claims that listening is not a receptive mode. It is a method of exploration, a way of walking through the soundscape. She suggests that this knowing is the experience of sound as a temporal relationship. This relationship is not something that is between things but is itself the thing, is sound itself. (Ibid.: 4-5) This idea describes the agency of a listener who simultaneously perceives and designs his or her sound world, or a sonic experience. For Krishna devotees, as discussed above, there are different layers of inhabiting this specific world, and through practising and developing the skill of chanting, devotees can design their experiences accordingly.

One of the highest levels is, as Gita Nagari das referred to, "seeing God face to face". It is the experience that the devotees constantly mention when explaining the meaning of the holy name. Seeing the face of God is a way of describing the experience that some have of the sound of God's name and God himself being the same. Taking both the words of Voegelin and the devotees seriously, I would suggest that this is the experience in which devotees sense the presence of Krishna or the relationship with him not through the medium of sound but 'in' sound itself.

Srila Prabhupada explains it further as there being two kinds of expansion of the Lord: Vishnu-tattva and jiva-tattva. Visnu-tattva means the expansions that are considered equal to God Himself. Jiva-tattva means God's expansion into living entities that are not equally powerful as God. But the expansion of Visnu-tattva is equally powerful, and therefore as good as God himself. Srila Prabhupada explains that this Hare Krishna mantra is the expansion, incarnation, and sound incarnation of God. He clarifies that this is not representation. He claims that God presents himself in this form of sound because humans cannot see God with their present, material eyes. But one can spiritualise these sense organs by associating with this transcendental incarnation, this 


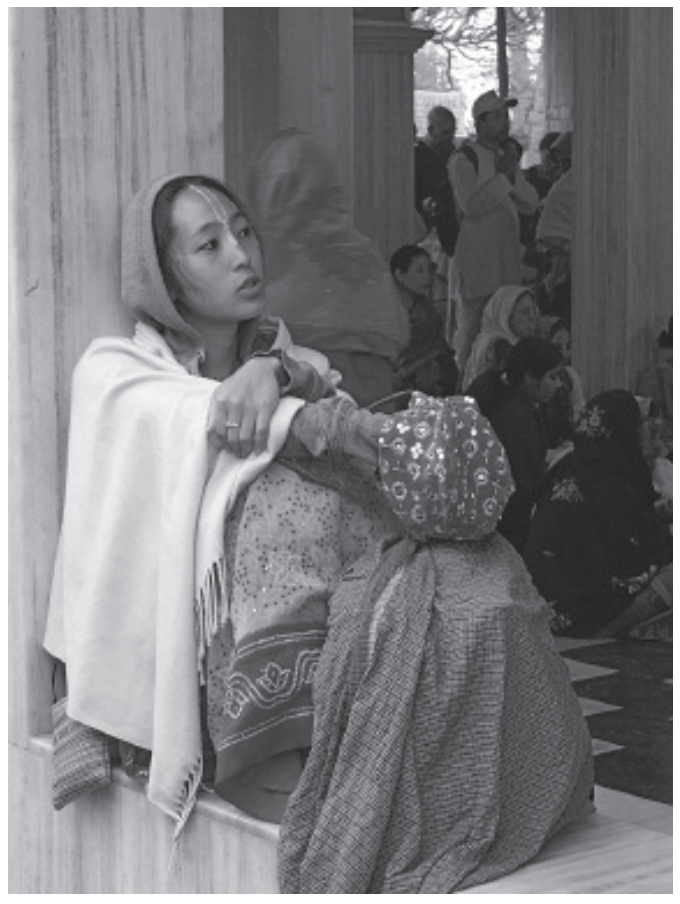

Photo 4. Yuka Arai chanting the Hare Krishna mantra on prayer beads. Photo by Marje Ermel. sound incarnation of God. Then one will gradually become godly. He says: "So by God's inconceivable potency, He can present before yourself in sound incarnation. That is His potency. That is His potency. He can do that. And therefore this name, Krsna, and the Supreme Lord Krsna, there is no difference." (Advaita Candra Dasa et al. 2011: 5-6)

Radhika Devi Dasi, an elderly woman from the Netherlands who has lived in India for many years and whose major interests are Sanskrit texts and poetry, gave me a better insight into what this level of realisation means. What does it mean to experience how the sound of God's name and God himself are the same, and what does it mean when devotees say that through chanting one can see God face to face? She proposed that this intimate realisation and knowledge was considered to be very high level and not so easily reachable in devotees' experience. She explained that in Vedas there were four levels of sound. The lowest level on which we operate is called vaikhari - this is related to our senses, to our physical self and is mainly connected to our speech. Madhyama refers to thinking in one's mind, without making a physical sound. The next two levels are pashyanti and para vak. Para vak, the highest level, means the highest speech and refers to God's words in the scriptures. We were both particularly interested in the third level, pashyanti, which means 'to see'. According to Aradhika, at this level one cannot distinguish the ear and the eye, meaning that if one says Krishna, Krishna is there. This means that Krishna and his name are the same. Aradhika explained that "On the level of pashyanti all the senses are merging into one and that level is not at the eye, or the visual level, but the level on which seeing is 'sound"'.

The level of pashyanti, which enables the devotees to 'see' God through sound and realise that the name of God and God himself are one, is a level of syneasthetic experience at which there is a blending or overlapping of the senses. Hanna Järvinen (2006: 72) explains that the early 19th-century physiological research on misperceptions and sensory stimuli developed the understanding of synaesthesia. Even though the research made the senses into unreliable reflections of the external world, it was believed that the transcendental quality could be found through synaesthetic experiences. In his writings about Zulu dreamscapes, David Chidester (2009: 350) also suggests that even though senses are limits, they can also be seen as providing the potential for extraordinary experience. He explains that eyes can be limited, but in the experience of a shaman, for example, it is important to have the ability to 'see'. Like metaphors, the senses enable us to transcend the limits of ordinary perception. Chidester claims that in religious discourse synaesthesia can evoke intense, extraordinary and unifying perception. 
At this syneasthetic level of pasyanti, one can reach beyond the duality of the material and non-material, the hidden and the manifested realms, or the 'inner' and 'outer' levels of sound. As Radhika said, at this level, "One knows that Krishna and His name are non-different". She explained:

And then we also see that everything is Krishna. Like Prabhupada... just before he left the planet he said, "there is only Krishna." It's not something you imagine, but it's actually true. This is also why advanced devotees experience so many symptoms. You are chanting and all these symptoms are coming. This is not imaginary... like sweating, hair standing on the end, crying, rolling on the floors, laughing... these are all the effects of the chanting. And these are very... you can say 'hands on' and visible. Very visible.

A. Whitney Sanford (2002: 57) also suggests that when devotees 'see' Krishna, they are not having a vision based on memory or the imagination, but they are seeing something real. She claims that, "this syneasthetic transformation is a portal to Krishna's world". This resembles what theologian Philip Sheldrake (2001: 71), who has studied the Catholic place, calls "catholicity" because in the catholic sense the divine presence cannot be imprisoned in any contracted place or series of places. He suggests, showing that the change of a person's whole sensory experience enables a person to perceive the sacred, that the particularities of places may point beyond themselves to the mystery of God in the sacramental sensibility. He states:

A sacramental sensibility understands the divine to be accessible through the human, the universal through the particular, the transcendent through the contingent, the spiritual through the material, the ultimate through the historical. [...] [A] sacramental sensibility enables us to affirm that God's presence is active in the space of the world, not merely within a gathered and purified Church. (Ibid.: 71)

For Krishna devotees, in a similar vein, at this intimate level that one can reach through sound, Krishna comes out from hiding and thus also the world that a devotee otherwise may perceive as material becomes Krishna. Like the concept of catholicity or sacramental sensibility, pashyanti is a sensory experience in which devotees perceive Krishna's presence in particular things and places. They feel that Krishna who is believably a person, the Supreme Personality of Godhead residing in the highest spiritual planet Goloka-Vrindavan or in the temples in the form of a deity, is also present and "active in the space of the world". And, as the devotees believe, through developing the proper skills of chanting and hearing the names of the Lord, one can experience this presence in one's chanting and ultimately in one's everyday life.

\section{CONCLUSION}

I have suggested, relying on the experiences of Krishna devotees, that the way one 'listens' to the world is not naturally given but is rather a skill that one can learn. I have explored how, through the process of skilful listening, one can reach a particular way of perceiving the world. At this level, a devotee can simultaneously experience the hidden and manifested realms and internal and external levels of sound in which Krishna and the sound of his name become inseparable. 
To achieve this experience, one has to develop not only the skill to focus on sound itself, but also some of the more existential human qualities. These qualities, such as humility and gratitude, allow devotees to reach or develop a certain level of mood or consciousness that helps them sing and hear the sound of the holy name properly and develop an intimate engagement with Krishna. This has been described as a stage of fulfilment in which one has no desires or thoughts other than those connected with God. The only desire is to serve God and His devotees. This is considered the proper mood and consciousness both for leading kirtan and chanting on prayer beads. This mood is one of service in which one's personal thoughts and desires rest in silence, or as Srila Prabhupada has said, resting in the sound of Krishna. Voegelin (2010: xv) has written that silence is not the absence of sound but the beginning of listening as communication. What becomes perceivable in the silent sound of Krishna, or perhaps simultaneously audible and visible, is also the relationship and communication between a devotee and God. This is the silence in which the sound of kirtan can emerge. As another Kirtan Academy teacher Sitala Devi Dasi suggested, "only if devotees' sincerity is welcomed by the Lord can they do good kirtan as the Lord is the one who empowers their voice to touch the hearts of others".

While exploring the skills the devotees were encouraged to learn for successful chanting and listening, I often felt the need to develop similar skills in order to grasp life in the field as an anthropologist. Devotees say that chanting japa is like a mirror, "it shows you clearly where your mind is, and thus how clean your heart is". They emphasise that attentiveness, humility, and gratitude help to calm the mind down and open the self to hear the sound. As anthropologists, we can easily find the field site to be a mirror of our minds and hearts. The skills and qualities we have are the tools to create an intimate engagement with the people we study and the sensuous world we come to share.

I agree with Stoller (1997: 136) that the most important and complicated lesson that a sensuous scholarship is facing is that of humility. He writes, "No matter how learned we may become, no matter how deeply we have mastered a subject, the world, for the sensuous scholar, remains a wondrous place that stirs the imagination and sparks creativity." Thus, no matter how knowledgeable we are of the place and the people we study, life is always greater than us and constantly challenges our knowledge and experiences. Humility allows us to be flexible enough to notice what life offers and to reconsider our ways of being-in-the-world. As Sacinandana Swami (2010 [2006]: 16) has said about the holy name, "Just as an ocean offers many unexplored depths, the nectarean ocean of the holy name similarly holds greater and greater mysteries for the spiritual seeker". Thus, joining the Krishna consciousness, as Gita Nagari Das said, and 'becoming' an anthropologist are both lifelong endeavours when one learns how to be a skilful listener to truly understand and reach intimacy with both the hidden and the manifested world. 


\section{SOURCES}

Author's fieldwork in Mayapur, West Bengal, India, March 2013-June 2014.

Bhakti Brhat Bhagavat Swami

Doyal Gouranga Das

Gita Nagari Das

Premalata Devi Dasi

Radhika Devi Dasi

Sitala Devi Dasi

Vikram Aditiyan

Yasomati Devi Dasi

\section{REFERENCES}

Advaita Candra Dasa, Danakeli Dasi, Dharmasetu Dasa, Mahamaya Dasi, Pyari Mohana Dasa and Srutadeva Dasa. 2011. Chanting Hare Krishna: The Art of Mystic Meditation, Kirtan, and Bhakti Yoga. Compiled from the Teachings of His Divine Grace A. C. Bhaktivedanta Swami Prabhupada. Los Angeles, CA: The Bhaktivedanta Book Trust.

Barcan, Ruth. 2011. Complementary and Alternative Medicine: Bodies, Therapies, Senses. Oxford: Berg.

Bhaktivedanta Swami Prabhupada. 2009 [1972]. Bhagavad-Gita As It Is. Mumbai: The Bhaktivedanta Book Trust.

Bhaktivedanta VedaBase webpage. https://www.vedabase.com/en/bg/13/8-12 (accessed March 10, 2015).

Brewster, Genevieve. 2013. Crying for Krishna: Harnessing Emotions that Can Help us on our Spiritual Path. India: Gopinatha Publications.

Bull, Michael and Les Back, eds. 2004. The Auditory Culture Reader. London: Berg.

Chidester, David. 2009. Zulu Dreamscapes: Senses, Media, and Authentication in Contemporary Neo-Shamanism. - The Sixth Sense Reader, edited by David Howes. Oxford: Berg, 339-356.

Chion, Michel. 2012. The Three Listening Modes. - The Sound Studies Reader, edited by Jonathan Sterne. Oxon: Routledge, 48-53.

Csordas, Thomas J. 1994. The Sacred Self: A Cultural Phenomenology of Charismatic Healing. Berkeley, CA: University of California Press.

Dolar, Mladen. 2006. A Voice and Nothing More. Cambridge: MIT Press.

Feld, Steven. 2005. Places Sensed, Senses Placed: Toward a Sensuous Epistemology of Environments. - Empire of the Senses: The Sensual Culture Reader, edited by David Howes. New York, NY: Bloomsbury Publishing.

Gibson, James, J. 1979. The Ecological Approach to Visual Perception. Boston, MA: Houghton Mifflin.

Horden, Peregrine. 2000. Musical Solutions: Past and Present in Music Therapy. - Music as Medicine: The History of Music Therapy since Antiquity, edited by Peregrine Horden. Aldershot: Ashgate, $4-40$.

Ingold, Timothy. 2000. The Perception of the Environment: Essays on Livelihood, Dwelling and Skills. London: Routledge.

Järvinen, Hanna. 2006. Kinesthesia, Synesthesia and Le Sacre du Printems: Responses to Dance Modernism. - The Senses and Society 1 (1): 71-91.

LaBelle, Brandon. 2010. Acoustic Territories: Sound Culture and Everyday Life. New York, NY: The Continuum International Publishing Group.

Milton, Kay. 2002. Loving Nature: Towards an Ecology of Emotion. London: Routledge. 
Sacinandana Swami. 2010 [2006]. The Nectarian Ocean of the Holy Name. Switzerland: Saranagati Publishing.

Sanford, A. Whitney. 2002. Painting Words, Tasting Sound: Visions of Krishna in Paramānand's Sixteenth-Century Devotional Poetry. - Journal of the American Academy of Religion 70 (1): 55- 81.

Sheldrake, Philip. 2001. Spaces for the Sacred: Place, Memory and Identity. London: SCM Press.

Stoller, Paul. 1984. Sound in Songhay Cultural Experience. - American Ethnologist 11 (3): 559-570.

Stoller, Paul. 1989. The Taste of Ethnographic Things: The Senses in Anthropology. Philadelphia, PA: University of Pennsylvania Press.

Stoller, Paul. 1997. Sensuous Scholarship. Philadelphia, PA: University of Pennsylvania Press.

Zarrilli, Phillip. 2015. Making 'Sense' in Embodied/Enactive Modes of Actor Training and Performance. - Ritual, Performance and the Senses, edited by Michael Bull and Jon P. Mitchell. London: Bloomsbury Publishing, 121-136.

van Maas, Sander. 2008. Intimate Exteriorities: Inventing Religion through Music. - Religion: Beyond a Concept, edited by Hent de Vries. New York, NY: Fordham University Press.

Voegelin, Salome. 2010. Listening to Noise and Silence: Towards a Philosophy of Sound Art. London: Continuum. 